\title{
Mr. Justice Frankfurter on the Construction of Statutes
}

\author{
Wallace Mendelson*
}

The capital fact in the mechanism of modern States is the energy of legislatures.

Sir Henry Maine

Whoever hath an absolute authority to interpret any written or spoken laws, it is he who is truly the law giver.... Bishop Hoadley

In government too, form follows function. It is not blind chance that in democratic systems the power to make legislative policy is parceled out along with political responsiblity, while the function of fitting general law to concrete cases belongs to those who are made "independent" of political pressure. This is implicit in the separation of powers. The difficulty is that while legislative and judicial functions are distinct at their cores, their peripheral boundaries inevitably overlap, for law-making is not an exact science. Legislation is essentially a compromise between Utopia and the status quo, and rationality is seldom the key to compromise. Nor is luman foresight equal to the legislator's job. $\mathrm{He}$, like the rest of us, cannot anticipate all the implications of his policy nor fully comprehend his own purposes before the test of application. The common language in which statutes must be written is less than mathematically precise. Moreover, play must be allowed for the joints of the macline, for government after all is experiment. ${ }^{1}$ The legislator's inability, then, to provide specifically for every stubborn fact within the general ambit of his purpose must be made good by the judge. And so, their functions legitimately overlap in the narrow interstice between precept and concrete application. As Learned Hand has put it: ${ }^{2}$

... a judge is in a contradictory position; he is pulled by two opposite forces. On the one hand he inust not enforce whatever he thinks best; he must leave that to the common will expressed by the [legislature]. On the other hand, he must try as best he can to put into concrete form what that will is, not by slavishly following the words, but by trying honestly to say what was the underlying purpose expressed.

But, given this limited entree into the policy domain, judges sometimes go further. The line between the licit and the illicit is vague at best. Even for the most detached, the temptation to find one's hopes or fears in the

* Professor of Political Science, The University of Tennessee, Knoxville, Tennessee.

${ }^{1}$ Mr. Justice Jolnnson in Anderson v. Dunn, 19 U.S. (6 Wheat.) 204, 226 (1821).

2 Reproduced in DiIITARD, THE SPIRTT OF LIBERTY 109 (1952). 
"purpose" of a statute must be very great. Above all, our bench and bar are trained in the tradition of the common law whose judges in fact were law-makers. It would be hard to believe that the weight of the old tradition does not color this as it does so many other aspects of American government-including the legislative process itself. Certainly there is more than raw coincidence in the fact that many of our founding fathers who espoused the separation of powers simultaneously tried to abolish the common law system. ${ }^{3}$ But these are matters for another day. It will be enough for now to observe with Mr. Justice Frankfurter that while as recently as 1875 almost half the business of the Supreme Court was common law litigation, today cases not resting on legislation are all but mil. It follows that statutory construction is at or near the heart of the modern judicial process. ${ }^{4}$

Holmes' remark that "the meaning of a sentence is to be felt rather than ... proved ${ }^{\prime \prime}$ was an expression of the wholesome truth that the interpretation of a statute is an act of judgment. "When we talk of statutory construction we have in mind cases in which there is a fair contest between two readings, neither of which comes without respectable title deeds. [The reading of a law] can seriously bother courts only when there is a contest between probabilities of meaming." judges will give their own private policy preferences free play. Indeed there are those "who deem naive the notion that judges are expected to refrain from legislating in construing statutes." Others have a bias against bias. "Admonitions like that of Justice Brandeis ... that courts should leave even desirable enlargement to Congress will not by itself furnish the meaning appropriate for the next statute under scrutiny. But as is true of other important principles, the intensity with which it is held may be decisive of the outcome." 8

\section{I}

\section{THE LEGISLATIVE COMPROMISE}

Behind all the other difficulties is the cardinal fact that legislation, being essentially a compromise between conflicting views, must often speak in something less than logically compelling terms. This is the judge's dilemma. But far more than a mere matter of lawyer's techmique is involved. We are told that "the legislative way of hfe" is the essence of freedom under government.

3 See Pound, The SpIrIt of the Common Law 116 passim (1921).

4 Frankfurter, Some Refiections on the Reading of Statutes, 47 CoLUM. L. REv. 527 (1947).

5 United States v. Johnson, 221 U.S. 488, 496 (1911).

${ }^{8}$ Frankfurter, Some Reflections on the Reading of Statutes, 47 Corum.L. Rev. 527, 528 (1947).

$7 \mathrm{Id}$, at 535 .

8 Ibid. 
Legislation is a process slow and cumbersome. It turns out a product-laws - that rarely are liked by everybody, and frequently little liked by anybody .... [W] hen seen from the shining cliffs of perfection the legislative process of compromise appears shoddy indeed. But wlien seen from some concentration camp of the only alternative way of life, the compromises of legislation appear but another name for what we call civilization and even revere as Christian forbearance. ${ }^{9}$

In short, by the give-and-take of the legislative process we achieve an equilibrium of interests as the foundation for social peace. The alternative, at least until philosophers become kings, is suppression of dissent by might, myth, and money in the fashion of the dictators.

If social compromise is the essence of legislation, what is the true nature of the judicial function in the construction of statutes? Learned Hand suggests the answer: ${ }^{10}$

[P] rovided that the opportunity always exists to supplant [laws] when there is a new shift in political power, it is of critical consequence that they should be loyally enforced [by judges] until they are amended by the same process which niade them. That is the presupposition upon which the compromises were originally accepted; to disturb them by surreptitious, irresponsible and anonymous [i.e., judicial] intervention imperils the possibility of any future settlements and pro tanto upsets the whole system. Such laws need but one canon of interpretation, to understand what the real accord was. The duty of ascertaining its neaning is difficult enough at best, and one certain way of nissing it is by reading it literally, for words are such temperamental beings that the surest way to lose their essence is to take them at their face. Courts must reconstruct the past solution imaginatively $\dot{n}_{1}$ its setting and project the purposes wlich inspired it upon the concrete occasions which arise for their decision.

. These insights, of course, are not entirely new. They were suggested in principle at least as long ago as Heydon's Case. ${ }^{11}$ But application is another matter, as witness the old canon that prescribed strict construction of statutes in derogation of the common law and the corresponding tendency of judges to find in legislation a mere declaration of what the common law had always been. These particular devices for impeding the legislative way of hife are now, happily, of little importance. So too since 1936 we have obtained substantial freedom to compromise at least our economic differences by legislation without a haunting fear of frustration by judicial review. But if that old blunderbuss is now quiescent, its ends at times are served by the stiletto of statutory construction. There is evidence in the opinions of some of our highest judges of an unavowed canon that statutes im derogation of liberal (read New-Deal) principles are to be strictly con-

\footnotetext{
${ }^{9}$ Sartith, The Legiszattve Way of LIFe 91 (1940).

10 Dilliard, THe SPIRIT OF LiberTy 173-74 (1952). (Emphasis added.)

1176 Eng. Rep. 637 (1584).
} 
strued, while liberal measures are read as though the hopes of their instigators had been enacted without benefit of legislative compromise. It is not coincidence, of course, that those who follow this view are also apt to find in the Constitution a "preferred position" for certain chosen (not all) civil liberties-a position so preferred, indeed, as to overcome even the orthodox presumption of constitutional validity for legislative measures. ${ }^{12}$

Against such instrumentalism Mr. Justice Frankfurter rebels. For him, judicial lrumility (self-restraint) is the rule for the construction of constitutions and statutes alike. With Chief Judge Hand he would honor the legislative compromise, however slovenly and earthbound, just as he would respect the established tradition that constitutional doubts are to be resolved in favor of the legislative will. Thus would he reconcile the inevitable law-making function of judges with the constitutional bedrock of separated powers.

These generalities are brought to earth in a series of opinions that gloss the Fair Labor Standards Act (hereinafter called FLSA). As introduced to his colleagues by Senator Hugo Black in 1937, the embryo of that measure invoked the full scope of Congress' commerce power for the regulation of wages and working hours. Indeed, as Attorney General (later Mr. Justice) Jackson pointed out in committee, the bill "combines everything, and is an effort to take advantage of" every generous interpretation of the Commerce Clause then known, whether expressed in nuajority or dissenting opinions. ${ }^{13}$ After running the gauntlet of opposition by the United States Chamber of Commerce, the National Association of Manufacturers, the National Publishers Association, the National Association of Wood Manufacturers, the Cotton Textile Institute and the Anthracite Institute, among others ${ }^{14}$ the measure emerged in much compromised form. Full use of the commerce power had been abandoned in favor of coverage only for employees "engaged in commerce," or "in the production of goods for commerce" with the gloss that "an employee shall be deemed to lrave been engaged in the production of goods if such an employe was employed ... in any process or occupation necessary to the production thereof, in any state."15 In short, full recourse to the "Shreveport" and all other broad constructions ${ }^{16}$ of the national power had evaporated. Something less than

12 This view is seen most clearly in the concurring opinion of Mr. Justice Rutledge in United States v. C.I.O., 335 U.S. 106, 140 (1948).

13 Joint Hearings before the Senate Committee on Education and Labor and the House Committee on Labor on S. 2475 and H R. 2700, 75th Cong., 1st Sess., at 54, 58-62 (1937).

14 Forsyth, Legislative History of the Fair Labor Standards Act, 6 LAw \& CoNTEMrP. ProB. 464, 468-69 (1939).

15 Fair Labor Standards Act $\S \S 3(j), 6,7$, 52 Stat. 1061, 1062, 1063 (1938), 29 U.S.C. $\S \S 203(\mathrm{j}), 206,207$ (1952).

16 See note 13 supra and related text. 
all enterprises, or all workers, "affecting" interstate commerce were covered. On the other hand, Congress had gone part way along the "affectation" road by including workers engaged in processes or jobs necessary to production of goods for interstate trade.

Under the later provision, the Court, through Mr. Justice Frankfurter, had little difficulty in finding that maintenance employees of a loft building leased out for the manufacturing of goods for interstate trade were protected by FLSA. ${ }^{17}$ Only Mr. Justice Roberts of the old-guard dissented. Even similar workers in the separate office building of a producer for "interstate" commerce were held to be covered, although here two members of the Court dissented..$^{18}$ But what of maintenance men in a typical, general office building leased to a great variety of enterprises, including executive and sales offices of manufacturing and mining concerns? Here Mr. Justice Frankfurter, for the Court, drew the hine. ${ }^{19}$ Congress plamly had not exercised the full scope of its power. In construing the phrase "necessary to production" of goods for commerce, the Justice said: ${ }^{20}$

We must be alert ... not to absorb by adjudication essentially local activities that Congress did not see fit to take over by legislation. Renting office space in a building exclusively set aside for an unrestricted variety of office work spontaneously satisfies the common understanding of what is local business .... Mere separation of an occupation from the physical process of production does not preclude application of the ... Act. But remoteness $\ldots$ is a relevant factor in drawing the line. Running an office building as an entirely independent enterprise is too many steps removed from the physical process of the production of goods. Such remoteness is insulated from the ... Act by those considerations pertinent to the federal system which led Congress not to sweep predominantly local situations within the confines of the Act.

Justices Black, Douglas, Murphy and Rutledge thought otherwise, finding controlling significance, evidently, in a literal reading of the word "necessary" in the crucial coverage clause.

Surely, neither position is demonstrably true or false. But some such distinction as Mr. Justice Frankfurter made was inevitable if Congress' compromise between the exercise of all or none of its commerce power was to be respected. Moreover, any line that the Court might draw would be dialectically vulnerable, as such lines always are, when judged exclusively by bordering cases. Surely it is significant that while four Justices thought the Court liad not gone far enough, two thought it had gone too far. ${ }^{21}$

17 Kirschbaum v. Walling, 316 U.S. 517 (1942).

18 Borden Co. v. Borella, 325 U.S. 679 (1945), Stone, C.J., and Roberts, J., dissenting.

1910 East 40th St. Co. v. Callus, 325 U.S. 578 (1945).

20 Id. at $582-83$.

21 The dissent in Borden Co. v. Borella, 325 U.S. 679 (1945), would cover the principal case a fortiori. See the concurring opinion of the Chief Justice, 10 East 40th St. Co. v. Callus, 325 U.S. 578,585 (1945). 
Finally, as a matter of hindsight, it may be noted that by amendatory language in 1949 Congress made explicit what Mr. Justice Frankfurter and the Court had found implicit from the beginning. ${ }^{21 a}$ In short, the expansive views of the dissenters were repudiated by legislative act.

That more than disagreement as to the meaning of words is involved in these cases is suggested in the pattern of disagreement over other provisions of the same act. The Black bill originally prohibited child-labor in comprehensive language. ${ }^{22}$ But, unlike the fate of the original wage and hour coverage provisions, this was not inerely watered down; it was eliminated. Instead there was substituted simply a restriction upon the interstate shipment of child-made goods, i.e., "no producer, manufacturer, or dealer shall ship or deliver for shipment in commerce any goods produced in an establishment ... in or about which . . . child labor has been einployed." ${ }^{23}$ Does such language ("producer" etc., "ship", "goods produced," as defined in the act) apply to Western Umion because of its use of underage inessenger boys? To answer yes, said the Court, would require "a series of interpretations so far-fetched and forced as to bring into question the candor of Congress as well as the integrity of the interpretative process .... To translate this act ... into an equivalent of the bills Congress rejected is, we think, beyond the fair range of interpretation." 24 Here too, Justices Black, Douglas, Murphy and Rutledge dissented.

The same pattern of disagreenient may be seen in decisions under the "engaged in commerce" provision. All of the Justices agreed that a cook who prepared meals for maintenance-of-way employees of a railroad was not engaged in the production of goods for interstate trade, or in a related process or job. But was he "engaged in commerce"? The Court thought not. This clause, it was said, "covered every employee in the 'channels of interstate commerce' . . . as distinguished from those who merely affected that commerce." ${ }^{25}$ Justices Black, Douglas, Murphy and Rutledge again dissented. They could not believe that Congress had used its powers more "sweepingly" with respect to "production" than with respect to "activities ... in transportation or connected therewith ...."26

Often the alternatives between which a legislature was torn, and the nature of the resulting compromise, are more obscure than they are in the

21a 52 StaT. 1060, 29 U.S.C.A. $\$ 203$ (j) (1938), as amended. See 95 Cong. REC. 14868-81 (1949), especially at 14874 .

22 Section 7 of the original bill, S. 2475 and H.R. 7200, 75th Cong., 1st Sess. (1937).

23 Fair Labor Standards Act § 12 (a), 52 STAT. 1067 (1938), 29 U.S.C. \$ 212 (1952).

24 Western v. Lenroot, 323 U.S. 490, 508-09 (1945).

25 McLeod v. Threlkeld, 319 U.S. 491, 494 (1943). Cf. Alstate Construction Co. v. Durkin, 345 U.S. 13 (1953), where Mr. Justice Black went too far not only for Mr. Justice Frankfurter but for Mr. Justice Douglas as well. See note 42 infra.

26 McLeod v. ThrelkeId, 319 U.S. 491, 502 (1943). 
history of these FLSA provisions. But when Mr. Justice Frankfurter finds in the terms of a statute the pattern of a mute compromise, it too becomes a key to construction. In United States v. Atlantic Mut. Ins. Co., ${ }^{27} \mathrm{Mr}$. Justice Black, for the Court, found that Congress had not in the Harter Act altered the old judge-made admiralty rule that common-carriers cannot stipulate for immunity for their own negligence. Mr. Justice Frankfurter, with whom his brother Burton joined, dissented. For them this "legislation, as is so often the case, represents a conpromise among competing interests. The carriers were relieved of their judicially imposed 'insurers' liability. In return they were required to forego the possibility of avoiding by contract certain specified obligations. Finally, if those obligations were in fact performed, recovery against the carrier for damages to cargo due to faulty navigation was altogether disallowed. This provision ... necessarily expressed a rejection of the judicially conceived premise as to public policy which was the foundation of the decisions which antedated legislation, namely, that liability for negligent navigation was a necessary spur to the carrier's exercise of care. Since that premise has been discarded by Congress, no justification remains for us to revive it as a basis for striking down the agreement here in question." ${ }^{28}$ As Holmes, J., had put it: ${ }^{20}$

The major premise of the conclusion expressed in a statute, the change of policy that induces the enactment, may not be set out in terms, but it is not an adequate discharge of duty for courts to say: We see what you are driving at, but you have not said it, and therefore we shall go on as before.

In short, it is no more incumbent upon judges strictly to construe statutes in derogation of judge-made law than it is loosely to construe New-Deal measures-even in the interests of hiberalism. ${ }^{80}$

Of all the forms that legislative compromise may take, the most difficult is that which simply by-passes vital issues. Sometimes such avoidance is purposeful; often, perhaps, it is oversight. In either case, Mr. Justice Frankfurter is not apt to use the occasion to further his own ideas as to what the legislative rule should have been. For him the making of changes in established policy is peculiarly a legislative function. Judges, on the other hand, "are under a special duty not to over-emphasize the episodic aspects of life and not to undervalue its organic processes-its continuities

27343 U.S. 236 (1952).

28 Id. at 245.

29 Johnson v. United States, 163 Fed. 30, 32 (1st Cir. 1908).

30 For another case in which strict construction produced liberal results, see Schwegman Bros. v. Calvert, 341 U.S. 385 (1951). The measure at issue, the Miller-Tydings Act, had been vigorously opposed by the "New-Deal." Strangely, Mr. Justice Black joined in Mr. Justice Frankfurter's dissent. The Court's position was repudiated by Congress in the Roger's Act, 66 Srar. 632 , 15 U.S.C. \& 15 (1952). 
and relationships. For judges at least, it is important to remember that continuity with the past is not only a necessity but even a duty."

FISA provides: ${ }^{32}$

No employer shall ... employ any of his employees . . . for a workweek longer than forty hours . . . unless such employee receives compensation for his employment in excess of [forty hours] at a rate not less than one and one-half times the regular rate at which he is employed.

Congress apparently had not considered how this principle should be applied in the case of longshoremen who usually do not work steadily for one employer, but shift from one to another, often daily, as employment opportunities are offered. For some twenty years prior to FLSA, this problem had been handled by collective bargaining agreements whereby longshoremen were paid "straight time" during specified daylight working hours and "over time" for week-end and night work. With the acquiescence of entployers, labor union and government, this practice was continued after enactment of the wage and hour law. A few workers, about one in a thousand, did sometimes work more than forty hours per week for a single employer..$^{33}$ Rejecting their own union's collective bargain, they instituted an action for double damages under the act, asserting that night and weekend work had been so common in their employment that the contractual "straight time" pay could not be deemed their statutory "regular rate" of pay. Rather, they argued, such "regular rate" was the average received for all their work from any one employer including both "straight time" and "overtime." This claim was upheld by the Court. ${ }^{34}$

Had Congress meant to provide "overtime" on "overtime" in this manner? Had its purpose been to disturb a long-established, collectively bargained method of handling overtime pay in an industry whose work habits were necessarily too irregular to fit readily into the normal pattern? Presumably such considerations were at stake when in the Senate debates Mr. Walsh asked, "Next, does the bill affect collective bargaining agreements .. . between employer and employee?" and Senator Black answered, "It does not." ${ }^{35}$ In any case Mr. Justice Frankfurter, joined by Justices Jackson and Burton, thought the Court had gone too far. For him nothing in the statutory term "regular rate" required a technical construction divorced from the habits and usage of the industry. Moreover, he noted, Congress

31 Frankfurter, Some Refiections on the Reading of Statutes, 47 Corux. L. REv. 527, 53435 (1947).

32 Fair Labor Standards Act § 7(a) (3), 52 StaT. 1063 (1938), 29 U.S.C. $\$ 207$ (1952).

33 This background material comes from Mr. Justice Frankfurter's dissenting opinion in Bay Ridge Operating Co. v. Aaron, 334 U.S. 446, 477 (1948).

34 Bay Ridge Operating Co. v. Aaron, 334 U.S. 446 (1948).

35 81 Cong. REc. 7650 (1952). See also dissenting opinion in Jewell Ridge Corp. v. Local, 325 U.S. 161, 175-78 (1945). 
had found that in the Portal-to-Portal cases $^{36}$ FLSA had been, as Congress put it, "interpreted judicially in disregard of long-established customs, practices, and contracts between employers and employees" to the detriment of industrial peace. ${ }^{37}$ Here, thought the Justice, the Court was repeating the same mistake which Congress had found it necessary to undo in the Portal-to-Portal Act. Again, as in the cases referred to, Mr. Justice Frankfurter's dissenting views were vindicated by subsequent act of Congress. ${ }^{38}$ The same is true of his dissent from the Court's view that FLSA precludes bona fide settlement of genuine disputes on overtime pay and damages even where the employees were given the overtime compensation in full. ${ }^{39}$ There too his position had been that $t^{40}$

[for] purposes of judicial enforcement, the "policy" of a statute should be drawn out of its terms, as nourished by their proper environment and not, like nitrogen, out of the air. Before a hitherto familiar and socially desirable practice is outlawed [the court should have] at least ... a broad hint [from Congress].

The pattern suggested by these cases is emphasized in Professor E. M. Dodd's statistics. Examining all Supreme Court decisions involving FLSA in a crucial four year period he concludes: ${ }^{41}$

Employer victories would have been much more numerous if the views of the Chief Justice and of Mr. Justice Roberts had uniformly prevailed, but would have been few imdeed if Justices Black, Douglas, Murphy and Rutledeg had always been able to get one other member of the Court to agree with them. For hardly more than a third of the decisions were unanimous. There were dissents by Mr. Justice Roberts in twelve cases, by Mr. Chief Justice Stone in seven and by Mr. Justice Frankfurter in two-all of them dissents from decisions adverse to an employer. On the other hand, there were dissents by Mr. Justice Black in seven cases, by Mr. Justice Douglas in seven, by Mr. Justice Murphy in six, by Mr. Justice Rutledge [who was not on the bench during the whole period] in four ... all of them cases in which the Courts' decision was in favor of the employer.

If it be said that the thrust of Mr. Justice Frankfurter's interpretations of FLSA is conservative, the answer is short. The act is conservative. Its coverage provisions are obviously not calculated to include as much as

${ }^{36}$ Anderson v. Mt. Clemens Pottery Co., 328 U.S. 680 (1946) ; Jewell Ridge Corp. v. Local, 325 U.S. 161 (1945).

37 Portal-to-Portal Act, 61 StaT. 84, 29 U.S.C. \& 251 (a) (1952).

3863 STAT. 446, 29 U.S.C. $\$ 207$ (e), (f) (1952).

${ }^{39}$ Schulte Co. v. Gangi, 328 U.S. 108 (1946). Nullified by Congress in Fair Labor Standards Amendments of 1949, 63 STAT. 919, 29 U.S.C. § 216(c) (1952).

40 Schulte Co. v. Gangi, 328 U.S. 108, 121-22 (1946).

41 Dodd, The Supreme Court and Fair Labor Standards, 1941-1945, 59 HaRv. L. REv. 321, 372-73 (1946). 
Congress might have included. ${ }^{42}$ Nor could Mr. Justice Frankfurter find in its terms or history a design to disturb settled and thoroughly compatible social or industrial traditions at the act's periphery. In this he was vindicated in that on at least four occasions, as we have seen, Congress rejected expansive construction of its purposes and put in express terms the more moderate views that the Justice, among others, had found implicit in the original act.

Moreover, the charge of conservatism is particularly vulnerable in view of the Justice's concurrence in Gemsco $0^{43}$ and the Irrigation Workers case. ${ }^{44}$ In the former the Court sustained an administrative order which, in the interest of safeguarding FLSA standards, outlawed a long-established tradition of "home work" in the embroidery industry. But, unlike the Longshoremen's case, here the bench had the guidance of the administrator's experience and judgment as expressed in a wage order which Congress had authorized "on such terms and conditions as the Administrator finds necessary to carry out the purposes of such [order], to prevent the circumvention or evasion thereof, and to safeguard the minimum wage rates established therein." 45 In the Irrigation Workers case the issue was whether employees of a farmers' nutual irrigation company supplying water for the production of crops for interstate distribution were engaged "in any process or occupation necessary to the production" of goods for commerce, or, on the other hand, were "employed in agriculture" and so exempt from FLSA. A divided Court found the act applicable. In a brief concurring opinion, Mr. Justice Frankfurter observed that the case "presents a problem for construction which may with nearly equal reason be resolved one way rather than another .... The nature of the problem being what it is, I acquiesce in the judgment that commends itself to the majority of my brethren." 46 In other words, in a "toss-up" case the Justice, obviously unsure as to what Congress would have said if it had faced this specific issue, and without any established industrial tradition for guidance, followed the act's administrator and gave liberalisn the benefit of doubt. Here, with the Court, he was reversed by subsequent legislative action. ${ }^{4 \pi}$

Other decisions involving other legislation might be examined, but the Justice's approach in the cases discussed is typical and so is the pattern of

42 For Mr. Justice Frankfurter's views when Congress has exercised its full commerce power, see Polish Alliance v. Labor Board, 322 U.S. 643 (1944). Cf. Trade Comm'n v. Bunte Bros., 312 U.S. 349 (1941).

43 Gemsco, Inc. v. Walling, 324 U.S. 244, 269 (1945). Cf. Phelps Dodge Corp. v. Labor Board, 313 U.S. 177 (1941).

44 Farmers Irrigation Co. v. McComb, 337 U.S. 755, 770 (1949).

45 Fair Labor Standards Act \& 8(f), 52 STAT. 1065 (1938), 29 U.S.C. § 208(f) (1940).

46 Farmers Irrigation Co. v. McComb, 337 U.S. 755, 770 (1949).

47 Fair Labor Standards Amendments, 63 STAT. 917, 29 U.S.C. \& 213(a) (6) (1952). 
basic disagreement with the libertarians. ${ }^{48}$ In a word, Mr. Justice Frankfurter is not conservative in the sense that he is cold to generous, humanitarian attempts at social progress. His whole extra-court life is a refutation of such a charge. ${ }^{49}$ As judge he is conservative in the deeper sense that he would conserve the basic separation between judicial and legislative functions whereby the power of the people to govern themselves-well or badly -is insulated from judicial fiat. So much for the general problem. We turn now to some specialties.

II

SPECIAL PROBLEMS

\section{A. Stare decisis and the trend of legislation}

A peculiar problem in construction arises when the Supreme Court is called upon to reconsider its own earlier reading of a legislative measure. Abstractly nothing more is involved than a simple application of the principle of stare decisis. But suppose the original construction had elicited powerful dissents over such names, perhaps, as Holmes, Brandeis, or Stone. Suppose too that in the interim a shift in political power had been reflected on the bench, the new judges having gone to school, so to speak, to the great dissenters. Our premise, of course, is that the legislature has not seen fit to alter the statute in question though, perhaps, it had been urged to do so. Such is the background of Girouard v. United States. ${ }^{50}$ Three earlier decisions $^{51}$ flatly held that Congress had denied naturalization to persons, otherwise qualified, who refused on pacifist grounds to bear arms. Building upon great name dissents in the earlier cases, Justices Douglas, Black, Rutledge, Murphy and Burton held that the former decisions "did not [reflect] the correct rule of law," ${ }^{22}$ nor was there crucial significance in the fact that Congress, though persistently urged to do so, had not changed its ways.

Girouard's case is particularly striking because one who had dissented from the earlier position also participated in the reconsideration. Clearly

48 See, e.g., Railway Labor Ass'n v. U.S., 339 U.S. 142 (1950) ; Estate of Spiegel v. Comm'r., 335 U.S. 701 (1949) ; American Stevedores v. Porello, 330 U.S. 446 (1947); United Brotherhood of Carpenters v. U.S., 330 U.S. 395 (1947); United States v. Carbone, 327 U.S. 633 (1946) ; Elgin, J.\&E.R. Co. v. Burley, 327 U.S. 661 (1946) ; Poff v. Pennsylvania R. Co., 327 U.S. 399 (1946) ; Cornell Steamboat Co. v. U.S., 321 U.S. 634 (1944) ; Trade Comm'n v. Bunte Bros., 312 U.S. 349 (1941). Cf. Knauff v. Shaughnessy, 338 U.S. 537 (1950) ; Eichenlaub v. Shaughnessy, 338 U.S. 521 (1950).

49 See, e.g., Law and Politics, Occastonal Papers of Femix Frankfurter (Macleish \& Prichard eds. 1939).

50328 U.S. 61 (1946).

51 United States v. Bland, 283 U.S. 636 (1931); United States v. Macintosh, 283 U.S. 605 (1931); United States v. Schwimmer, 279 U.S. 644 (1929).

52 Girouard v. United States, 328 U.S. 61, 69 (1946). 
Mr. Justice Stone had thought the court originally had misconstrued the measure in question. But, as Chief Justice, he also dissented in Girouard. Three decisions of at least fifteen years standing, refusal by six successive Congresses to make vigorously urged changes, and, finally, re-enactment of the same provisions were decisive for him as for Justices Frankfurter and Reed. ${ }^{53}$

Mr. Justice Frankfurter's position in Girouard clearly does not turn solely upon the very special "legislative history" which the dissenters there emphasize. His deep respect for estabhished decisions is seen in case after case where no comparable evidence of congressional "adoption" is available. The Justice's position simply is that long-settled judicial construction of a statute, and established doctrines which have grown up around a statute, are part of the statute itself. Alteration then is a matter for the legislature. As one of his famous predecessors said, it is usually not so important that a law be "just," whatever that may mean, as that it be settled; for stability and predictability themselves are important elements in a healthy legal system. Moreover, "judicial legislation" of this type entails serious problems of retroactivity.

Accordingly, Mr. Justice Frankfurter could not accept a reinterpretation of the Mann Act which would save polygamists from its penalties; ${ }^{54}$ nor a departure from precedent that altered railroad liability under the Carmack Act; ${ }^{55}$ nor disregard of an ancient doctrine which prevented an assignor from raising the invalidity of his patent against the assignee; ${ }^{56}$ nor violation of a settled definition of "unseaworthy"; ${ }^{57}$ nor abandonment of long-established principles of negligence law where Congress has made "negligence" the test of liability for purposes of the Employers' Liability Act $;{ }^{58}$ nor departure from a settled construction of legislation concerning the reviewability of Interstate Commerce Commission orders denying reparations. ${ }^{59}$ The crux of the Justice's position in these cases is suggested in the following language which he endorsed in dissent: ${ }^{60}$

Of course the law may grow to meet changing conditions. I do not advocate slavish adherence to authority where new conditions require new rules of conduct. But this is not such a case. The tendency to disregard precedents in the decision of cases like the present has become so strong i $m$ this Court of late as, in my view, to shake confidence in the consistency of decision and leave the courts below on an unchartered sea of doubt and difficulty

\footnotetext{
53 Id. at 70-79.

54 Cleveland v. United States, 329 U.S. 14 (1946).

55 Reider v. Thompson, 339 U.S. 113 (1950).

56 Scott Paper Co. v. Marcalus Co., 326 U.S. 249 (1954).

57 Mahnich v. Southern S.S. Co., 321 U.S. 96 (1944).

58 Tiller v. Atlantic Coast Line R.R., 318 U.S. 54 (1943).

69 United States v. I.C.C., 337 U.S. 426 (1949).

60 Mahmich v. Southern S.S. Co., 321 U.S. 96, 113 (1944).
} 
without any confidence that what was said yesterday will hold good tomorrow ....

What Mr. Justice Jackson said in another context is relevant here: "I know of no way that we can have equal justice under law except we have some laws." 61

A related problem arises when the Court is asked to reconsider an interpretation of the Constitution after Congress, meanwhile, has acted in the light of the former decision. Such, in substance, is the South-Eastern Underweriters case. ${ }^{62}$ For seventy-five years the Court had held that the "business of insurance is not commerce" within the meaning of the Constitution. ${ }^{63}$ Twenty-one years after the beginning of that line of cases Congress, in the Sherman Act, had penalized restraints of interstate commerce. More than half a century later our problem came up. Had Congress penalized restrictive, interstate, insurance transactions? Justices Black, Douglas, Murphy and Rutledge held in the affirmative, and theirs was the prevailing view, for Justices Roberts and Reed did not participate. Chief Justice Stone and his brothers Frankfurter and Jackson dissented. For them it seemed plain, in the words of Mr. Justice Frankfurter, that by adopting the Sherman $\mathrm{Act}^{64}$

Congress did not mean to disregard the then accepted conception of the constitutional basis for the regulation of the insurance business [by the states]. And the evidence is overwhelming that the mapplicability of the Sherman Act, in its contemporaneous setting, to insurance transactions such as those charged by this indictment has been confirmed and not modified by Congressional attitude and action in the intervening fifty years.

There is a revealing difference in the attitude of the dissenters on the constitutional and the statutory questions involved. All agreed that the facts of business life had undermined the old judicial view that the insurance business is not commerce in the constitutional sense. To abandon a constitutional decision that has become an anachronism is one thing; to force that reversal retroactively upon an unsuspecting Congress is something else again. ${ }^{65}$

Helvering v. Griffiths ${ }^{66}$ raises a similar problem. In 1920 the Court had held that stock dividends were not constitutionally taxable as income, Jus-

61 Brown v. Allen, 344 U.S. 443, 546 (1953).

62 U.S. v. Underwriters Assn., 322 U.S. 533 (1944).

63 For the leading cases, see id. at 543.

$64 I d$. at $583-84$.

65 In Mr. Justice Frankfurter's view, apparently a similar problem was involved in Power Comm'n v. Hope Gas Co., 320 U.S. 591 (1944). See his concurring opmion in Driscoll v. Edison Co., 307 U.S. 104, 122 (1939), and compare Mr. Justice Black's position in these two cases with that of Mr. Justice Frankfurter.

66318 U.S. 371 (1943). 
tices Holmes, Brandeis, Day and Clarke dissenting. ${ }^{97}$ Thereafter, in 1936, for other purposes, the Court distinguished between different types of stock dividends, holding that some did constitute income in the constitutional sense. $^{.8}$ Then Congress amended the revenue laws to include as taxable income all corporate dividends excepting such as do "not constitute income within the meaning of the [Constitution]." ${ }^{69}$ A majority found in the legislative history of that provision a congressional purpose simply to include within its coverage such dividends as the 1936 decision permitted. The dividends in the principal case, not being within that category, were immune.

It is interesting that a large part of the legislative history in support of the Court's position came from remarks of Senator Hugo Black. ${ }^{70}$ Justices Hugo Black, Douglas and Murphy dissented. Mr. Justice Rutledge did not participate. In the minority view, Congress had not meant merely to go as far as possible while honoring both the 1920 and 1936 decisions. Rather, Congress had sought instead to "reverse" the 1920 decision-a reversal which the dissenters were willing to sustain. ${ }^{71}$ If, as the Court intimates, Mr. Black seemed less willing to compromise on a liberal cause in the one forum than in the other, that is a fair reflection, as has been suggested, of the difference between the judicial and legislative processes.

Although there is truth in the suggestion that every problem of construction is unique, a pattern seems evident in these cases. In all nine of them Mr. Justice Frankfurter constantly adhered to the principle that changes in established interpretations of legislative policy are matters for Congress. ${ }^{72}$ At the other extreme, only Justices Black and Murphy consistently by-passed precedent achieving thereby a more liberal legislative result. While Justice Rutledge did not participate in one case, only once did he and Justice Douglas differ with their brothers Black and Murphy. That involved the lost cause of polygamy.

But if Mr. Justice Frankfurter is more sensitive to the need for stability in judicial law than some of his colleagues, he is not hamstrung by stare decisis. Writing for the Court in Helvering v. Hallock, he abandoned the Court's most recent construction of an estate tax measure after careful exploration-too long for quotation here- of factors relevant to the judicial overruling of a point of statutory construction..$^{73}$

Ironically, a case of interpretation in which Mr. Justice Frankfurter

67 Eisner v. Macomber, 252 U.S. 189 (1920).

6s Koshland v. Helvering, 298 U.S. 441 (1936).

69 INT. Rev. CodE of 1939, § 115(f) (1), 53 Stat. 47 (now INT. REv. Code of 1954, § 305).

70 See Helvering v. Griffiths, 318 U.S. 371, 383-85 (1943).

71 Id. at 404-11.

72 See also note 65 suppra.

73 Helvering v. Hallock, 309 U.S. 106, 119-22 (1944). Cf. Nye v. United States, 313 U.S. 33 (1941); Rochester Telephone Co. v. U.S., 307 U.S. 125 (1939). 
found circumstances justifying a departure from precedent has brought him more criticism perhaps than any of his other ventures. That was United States v. Hutcheson, ${ }^{74}$ a criminal prosecution under the Sherman Act growing out of a labor union's secondary boycott. Doubtless many sponsors of the Clayton Act (labor's so-called magna charta) thought that measure had freed such activity from the taint of crime. But the Duplex decision ${ }^{75}$ in 1921 at least implied otherwise. Mr. Justice Frankfurter, for the Court, recognized that controversial case as relevant, unless Congress, meanwhile, had nullified it. Admittedly, Congress had not done so explicitly, but the Justice found that "the Norris-La Guardia Act has expressed the public policy of the United States . . . in terms that no longer leave room for doubt" 76 as to the legislative liquidation of Duplex. It followed that Hutcheson's demurrer to the indictment was properly sustained. Critics of the opinion urge that Norris-La Guardia had nothing whatever to do with the criminality of any conduct, but only with the jurisdiction of federal courts to issue labor injunctions. ${ }^{77}$ Some of Mr. Justice Frankfurter's language (when separated from the balance of what he says) invites this attack. ${ }^{78}$ But the Justice would hardly be so naive as to turn his case on the untenable proposition that foreclosure of federal injunctive relief ipso facto precludes federal prosecution. This part of his argument must be read in conjunction with what preceded and follows it. The Justice's position is simply that section 20 of the Clayton Act alone clearly would immunize Hutcheson's conduct from injunction and criminal prosecution under the Sherman Act. The Duplex decisions, however, by strained construction of the term "labor dispute," had destroyed the immunity from injunction and thereby raised questions as to the immunity from prosecution. Thereafter, Congress had rejected Duplex. As the House Committee on the Judiciary put it: ${ }^{79}$

The purpose of the [Norris-La Guardia] bill is to protect the rights of labor in the same manner the Congress intended when it enacted the Clayton Act ... which act, by reason of its construction and application by the Federal courts, is ineffectual to accomplish the congressional intent.

The crux of the matter is that in the Clayton Act, and then again in the Norris-La Guardia Act, Congress defined the concept of a legitimate "labor dispute" broadly to protect the Hutcheson type of activity, while Duplex defined that crucial legislative term more narrowly. Mr. Justice Frankfur-

\footnotetext{
74312 U.S. 219 (1941).

75 Duplex Co. v. Deering, 254 U.S. 443 (1921).

76 United States v. Hutcheson, 312 U.S. 219, 234 (1941).

77 See, e.g., Gregory, Labor and the Law 269 et seq. (1946).

78 United States v. Hutcheson, 312 U.S. 219, 234-35 (1941).

${ }^{79}$ Quoted id. at 236.
} 
ter accepted the congressional, rather than the Duplex, definition. To be sure, the Norris-La Guardia re-definition occurred in a purely anti-injunction context-the only context in which the Court had erred. But the fact that Congress fashioned the "punishment to fit the crime," did not, in Mr. Justice Frankfurter's view, detract from its primary purpose, as the House Judiciary Committee said, to "protect the rights of labor in the same manner the Congress intended when it enacted the Clayton Act . . .." Mr. Justice Frankfurter's critics read the Norris-La Guardia "intent" narrowly in the light of the remedy which it afforded. Thus, for them, while Congress clearly wanted to kill Duplex injunctions, it simultaneously wanted Duplex to live on as the authoritative interpretation of the Clayton Act in criminal matters. Perhaps so, but there is no hint of such a design in the act's section 2 "preamble." Indeed, the latter is expressed in terms fully adequate to introduce section 20 of the Clayton Act itself. That, no doubt, is why Mr. Justice Frankfurter referred particularly to the "preamble" when he said that Congress in Norris-La Guardia had "exphicitly formulated the 'public policy of the United States' in regard to industrial conflict, and by its light established that the allowable area of union activity was not to be restricted, as it had been in the Duplex case . . ." Thus, Congress had uprooted all, not just a part, of the Duplex error.

In short, the Sherman, Clayton and Norris-La Guardia Acts are treated as "interlacing," not isolated, events. They were read together in the context of the problems, including the litigation, which gave rise to them. As the Justice put it elsewhere, "A legal fagot ought not to be broken into verbal sticks." 81 Both before and since, Mr. Justice Frankfurter has sought meaning, where the text is not free from doubt, by a process of construction which in effect is the ascertainment of policy imminent in a legislative trend of whicl the statute at issue is one element. ${ }^{82}$ History is a seamless web for

$80 \mathrm{Id}$. at 231. As noted above, Mr. Justice Frankfurter took the position in US. v. Under writers and Helvering $v$. Griffiths that a statute must be construed in the liglit of constitutional doctrines in vogue at the time of its enactment. He did not depart from that doctrine in Hutcheson. Of course Norris-La Guardia was passed in contemplation of Truax v. Corrigan, 257 U.S. 312 (1921), whicl liad lield invalid a state act in part on the due process ground that it "withheld from the plaintiffs all remedy for the wrongs they suffered." Hutcheson's case does not construe Norris-La Guardia to foreclose anything but equitable remedies. The point is, Mr. Hutcheson was saved by the Clayton Act-the act that did explicitly foreclose both legal and equitable remedies (its liaving been enacted prior to the Truax case). In short, the Hutcheson construction of Norris-La Guardia did not read into that act a constitutional risk that Congress had been unwilling to take! Nor, indeed, did Hutcheson inake the Clayton Act "more" unconstitutional than it had been. At worst, in this respect it made that measure vulnerable to a Truax attack by victims of secondary boycotts, whereas previously only victims of more direct labor pressure would have been in a position to raise the issue. To put it differently, while Norris-La Guardia fertilizes Clayton, it is also severable therefrom.

81 Reider v. Thompson, 339 U.S. 113, 120 (1950).

82 Andres v. Umited States, 333 U.S. 740 (1948) ; Keifer \& Keifer v. R.F.C., 306 U.S. 381 (1939). See also note 36 supra and related text. 
legislators no less than for judges. Like a line of cases, a series of statutes oft-times reveals a significance not explicit in any of its isolated parts. ${ }^{83}$

Congress, as we have seen, has not been reluctant in recent years to override judicial constructions which it deems too liberal. Yet Hutcheson still stands. Indeed the case for congressional vindication of Mr. Justice Frankfurter's position may be put more strongly. While Congress in the Taft-Hartley Act thoroughly overhauled national labor law-it even provided sanctions, including injunctions, against secondary boycotts ${ }^{84}$-it has not restored any form of criminal penalty upon the Hutcheson kind of labor umion activity.

\section{B. Federalistic Considerations}

If respect for the division of labor between Court and Congress is at or near the core of Mr. Justice Frankfurter's jurisprudence, regard for the division between Nation and States is not far removed. As Professor Jaffe put it: ${ }^{85}$

[The Justice's] conception of the role of the judge is at the same time exalted and self-moderating. He is forever disposing of issues by assigning their disposition to some other sphere of competence. His world is the urban world of the division of labor, of the specialist, the expert. He is the craftsman conscious and proud of the illusive niceties of his own skill and, in consequence, scrupulous in his regard for the integrity of impinging spleres of competence.

He does not share the unspoken attitude of some that the Court is not merely a super-legislature, but a super-government always ready and competent in every sphere of human activity. Cases turning upon the meaning of state law-like those involving the meaning of national law-often present problems in the division between State and Nation, as well as problems in the separation of legislative and judicial functions. Here judicial humility is doubly grounded. Thus, in Mr. Justice Frankfurter's view, state courts are the proper forum for the construction of state statutes where a constitutional or other federal question may be avoided or delimited by a preliminary state decision on state law. It is not so much a matter of economy of effort as of avoiding needless embarrassment to federal-state relations which might result if a federal court should decide a federal issue on a gratuitously wrong impression of state law. Certainly nothing that a federal court might say as to what state legislation means could be authorative.

83 See Harack, The Common Law of Legislation, 23 Iowa L. REv. 41 (1937).

84 Labor Management Relations Act (Taft-Hartley Act) § 8(b) (4)(A), 61 STAT. 141, 29 U.S.C. $\$ 158(\mathrm{~b})(4)(\mathrm{A})$ (1952). (1949).

85 Jaffe, The Judicial Universe of Mr. Justice Frankfurter, 62 Harv. L. Rev. 353, 359 
So, in a case that arose in a federal court and turned upon the meaning of a Texas statute, the Justice said: ${ }^{86}$

$[N]$ matter how seasoned the judgment of the district court may be, it cannot escape being a forecast rather than a determination. The last word on the meaning of [the act] belongs neither to us nor to the district court but to the supreme court of Texas. In this situation a federal court of equity is asked to decide [a constitutional] issue by making a tentative answer which may be displaced tomorrow by a state adjudication .... The reign of law is hardly promoted if an unnecessary ruling of a federal court is thus supplanted by a controlling decision of a state court. The resources of equity are equal to an adjustment that will avoid the waste of a tentative decision....

.... We therefore remand the cause to the district court, with directions to retain the bill pending a determination of proceedings, to be brought with reasonable promptness, in the state court in conformity with this opinion.

In this case the constitutionality of the statute was in issue. Doubtless that consideration was controlling for at least some who joined in Mr. Justice Frankfurter's opinion. It was not for him! As he said in dissent elsewhere: ${ }^{87}$

[T] hough no constitutional issue is present, regard for the respective orbits of State and federal tribunals is the best of reasons, as a matter of judicial administration, for requiring a difinitive adjudication by the New York courts rather than proceeding on the basis of our own tentative guess as to the meaning of the New York statutes. That federal issues may remain is no justification for refusing to submit to the New York courts a separable issue of New York law.

But when a controversy had dragged on for years in the federal courts, the Justice was willing to construe a state measure in order to avoid further delay. ${ }^{88} \mathrm{So}$, too, in an interstate compact case he was prepared to override a state supreme court's reading of state (constitutional) law when the interests of other states were at stake.

A state cannot be its own ultimate judge im a controversy with a sister state.... Two prior decisions of this Court make clear ... that we are free to examine determinations of law by state courts in the limited field where a compact brings in issue the rights of other states and the United States. ${ }^{89}$

More familiar federalistic considerations are involved in the reading of national legislation. Recognizing the broad scope of congressional power to regulate affairs which in at least some aspects are largely local, ${ }^{90}$ the Justice

86 Railroad Comm'n v. Pullman Co., 312 U.S. 496, 499-500, 501-02 (1941).

87 Propper v. Clark, 337 U.S. 472, 497 (1949). See also Justice Frankfurter's opinion in Sutton v. Leib, 342 U.S. 402, 412 (1952), and compare that in Burford v. Sun Oil Co., 319 U.S. 315,336 (1943), where, apparently, the Justice considered the federal issue as only minor.

88 Public Utilities Comm'n v. Gas Co., 317 U.S. 456 (1943).

89 Dyer v. Sinss, 341 U.S. 22, 28 (1951).

80 Polish Alliance v. Labor Board, 322 U.S. 643 (1944). 
is no friend of excursions into the state domain by loose construction. It is not to be forgotten that in this context congressional measures cut two ways; they carry national policy into a state, and they displace local policy. Thus, two levels of legislation will often be at stake in the interpretation of a federal statute. In such cases much depends upon the willingness or unwillingness of judges to stretch the meaning of what Congress has said.

In Palmer v. Massachusetts ${ }^{01}$ Mr. Justice Frankfurter observed: ${ }^{22}$

$[\mathrm{M}]$ eaning is sought to be derived not from specific language but by fashioning a mosaic of significance out of the innuendoes of disjointed bits of a statute. At best this is subtle business ... . Especially is wariness enjoined when the problem of construction implicates one of the recurring phases of our federalism and involves striking a balance between national and state authority in one of the most sensitive areas of government .... [I]n construing legislation this Court has dis-favored inroads by implication on State authority ....

In case after case where a divided Court has found incompatability between national and state legislation, Mr. Justice Frankfurter has been in dissent.

To construe federal legislation so as not needlessly to forbid preexisting State authority is to respect our federal system. Any indulgence in construction should be in favor of the States, because Congress can speak with drastic clarity whenever it chooses to assume full federal authority, completely displacing the States. ${ }^{93}$

Moreover, he said: ${ }^{94}$

[T] require the various [administrative] agencies of the government who are the effective authors of legislation like that now before us to express clearly and explicitly their purpose in dislodging constitutional powers of the States-if such is their purpose-makes for care in draftsmanship and for responsibility in legislation.

\section{Avoidance of Constitutional Issues}

On one principle of construction there has been universal agreement throughout our history-what Congress has written "must be construed with an eye to possible constitutional limitations so as to avoid doubts as to its validity." ${ }^{55}$ Or in the words of Chief Justice Taft: "[I]t is our duty in the interpretation of federal statutes to reach a conclusion which will

01308 U.S. 79 (1939).

02 Id. at 83,84 .

93 Bethlehem Co. v. State Board, 330 U.S. 767, 780 (1947).

${ }^{94}$ Cloverleaf Co. v. Patterson, 315 U.S. 148, 178 (1942). See Bus. Employees v. Wisconsin Board, 340 U.S. 383 (1951) ; Rice v. Santa Fe Elevator Corp., 331 U.S. 218 (1947); Hill v. Florida, 325 U.S. 538 (1945); Baltimore \& Ohio R. Co. v. Kemper, 314 U.S. 44 (1941).

${ }^{95}$ Lucas v. Alexander, 279 U.S. 573, 577 (1929). See also Chief Justice Marshall in Ex parte Randolph, 20 Fed. Cas. 242, 254, No. 11558 (C.C.D. Va. 1833). 
avoid serious doubt of their constitutionality." ${ }^{96}$ But precept is one thing and practice another. In law, as elsewhere, men readily confuse personal values with the requirements of the cosmos. Judges who feel deeply need not wait with Job's patience for the opportune case to write their values into constitutional law. Nothing is easier than to read a straw-man into a legislative measure and then strike him (and it) down. ${ }^{97}$ In this regard the Roosevelt-Truman Court has an enviable record. Indeed, if paucity of interference by judicial review proves a high regard for construction that favors constitutionality, the Roosevelt-Truman Court has a record unmatched since the Civil War. On only two occasions in the past eighteen years has it struck down acts of Congress. ${ }^{98}$ But this abstinence of the Court is not reflected evenly in the attitude of all its members. If some of the "nine old men" found it difficult to resist writing their economic views into the Constitution, some of their successors appear to have similar difficulties in another area. In at least four cases ${ }^{99}$ involving civil liberty Justices Black and Douglas have found it fitting to raise and pronounce upon issues of constitutional law which others thought could be avoided by reasonable statutory construction. Justices Murphy and Rutledge agreed in each of the three cases in which they participated. Per contra, Mr. Justice Frankfurter, attaining the same immediate results, found it possible to avoid constitutional commitment. Is the difference merely one of form? Perhaps it is, if one looks no further than the effect upon the immediate litigants. But Mr. Justice Frankfurter is too sensitive to history to take so narrow a view-and too respectful of the social needs that are reflected in the principle of stare decisis.

Particularly when congressional legislation is under scrutiny, every rational trail must be pursued to prevent collision between Congress and Court. For Congress can readily amend its ways, or the people may express disapproval by choosing different representatives. But a decree of unconstitutionality by this Court is fraught with consequences so enduring and farreaching as to be avoided unless no choice is left in reason .... [T] he most fundamental principle of constitutional adjudicaion is not to face constitutional questions, but to avoid them, if at all possible. And so [as Brandeis, J., observed] the "Court developed, for its own governance in cases confessedly within its jurisdiction, a series of rules under which it has avoided passing upon a large part of all constitutional questions pressed upon it for decision"... . Some of these rules may well appear over-refined or evasive to the laity. But they have the support not only of the profoundest wisdom.

${ }^{98}$ Richmond Co. v. United States, 275 U.S. 331, 346 (1928).

97 See Mendelson, John Marshall's Short Way With Statutes, 36 Ky. L.J. 284 (1948).

98 United States v. Lovett, 328 U.S. 303 (1946); Tot v. United States, 319 U.S. 463 (1943).

99 United States v. Rumely, 345 U.S. 41 (1953); United States v. C.I.O., 335 U.S. 106 (1948); United States v. Lovett, 328 U.S. 303 (1946); Hannegan v. Esquire, 327 U.S. 146 (1946). Cf. Jordan v. DeGeorge, 341 U.S. 223 (1951). 
They have been vindicated, in conspicuous instances of disregard, by the most painful lessons of our constitutional history..$^{100}$

Above all a decent respect for a sister branch of government requires that constitutionalism should be particularly avoided where "Congress has [not] demonstrated its full awareness of what is at stake by unequivocally" exercizing the challenged power. ${ }^{101}$

III

\section{CONCLUSION}

What words convey to us often depends upon what is uppermost in our minds-and hearts; for language is a vessel into which, while it contains some wine, usually more can be poured. Preoccupation with business interests may induce one construction of a statute; a deep concern for the common man may yield something quite different. Both will find support in logic, in history and ultimately in something deemed transcendental. But this is the domain of legislature. The difficulty is that the statutory vessel is seldom full, and to perform his own function properly the judge must fill it. Shall he add his favorite wine, or is there some subtle alchemy that will enable him merely to make incarnate what is already there. Some say it is the judge's duty to add what is his own. ${ }^{102}$ Others, including Learned Hand, suggest he can do no other; and that

[his] conclusions, when their bases are sifted, always reveal a passional foundation. Even so, though [those conclusions] be throughout the creatures of past emotional experience, it does not follow that experience can never predispose us to impartiality. A bias against bias may be as hkely a result of some buried crisis, as any other bias. Be that as it may, we know that men do differ widely in this capacity; and the incredulity which seeks to discredit that knowledge is a part of the crusade against reason from - which we have already so bitterly suffered. We may deny-and if we are competent observers, we will deny - that no one can be aware of the danger and in large measure provide against it. ${ }^{103}$

Chief Judge Hand's life is a monument to this insight. As Mr. Justice Frankfurter put it with respect to Justices Holmes, Brandeis and Cardozo: ${ }^{104}$

A judge of marked individuality stamps his individuality on what he writes, no matter what the subject. What is however striking about the opinions of

100 United States v. Lovett, 328 U.S. 303, 319-20 (1946).

101 United States v. Rumely, 345 U.S. 41, 46 (1953).

102 Cahn, Authority and Responsibility, 51 Convas. L. Rev. 838 (1951). Cf. Braden, The Search For Objectivity in Constitutional Law, 57 YaLE L.J. 550, 594 (1948).

103 Reproduced in DifIIARD, THE SpIRIT of LIBERTy 218 (1952).

${ }^{104}$ Frankfurter, Some Refiections on the Reading of Statutes, 47 CoLUm. L. REv. 527, 531 (1947). 
the three Justices in this field is the essential similarity of their attitude and their appraisal of the relevant. Their opinions do not disclose a private attitude for or against extension of governmental authority by legislation, or towards the policy of particular legislation, which consciously or imperceptibly affected their judicial function in construing laws.

In a word the genius of a great judge in the reading of statutes lies not in a bias for this or that tactical value, however worthy, but in his respect for the limits of his own function-for that grand strategic division of labor between legislature and court, between Nation and State. 